\title{
RADIATION SYNTHESIS OF POLY(VINYL ALCOHOL) PVA-(POLYVINYL PYRROLIDONE) PVP FOR IMMOBILIZATION OF CAPTOPRIL
}

\author{
Hariyanti $^{1}$, Erizal ${ }^{2}$, M. Yasin Yunus ${ }^{2}$, Indah Lestari ${ }^{3}$ and Ditri Risska Rahmadhani ${ }^{1}$ \\ ${ }^{1}$ Faculty of Pharmacy and Science, Prof. Dr HAMKA University Muhammadiyah \\ Klender, Jakarta Timur \\ ${ }^{2}$ Centre for Application Isotope and Radiation \\ Jl.Cinere, Jakarta Pusat \\ ${ }^{3}$ Faculty of Mathematics and Science, Indonesia University \\ Kampus Baru UI, Depok \\ E-mail:izza3053@yahoo.com
}

Received: 6 April 2020

Revised: 1 July 2020

Accepted: 3 July 2020

\begin{abstract}
RADIATION SYNTHESIS OF PVA POLY(VINYL ALCOHOL)-PVP (POLYVINYL PYRROLIDONE) for IMMOBILIZATION OF CAPTOPRIL. The aim of this work is to prepare Polyvinyl alcohol (PVA)- Polyvinylpyrrolidone (PVP) hydrogel with varying irradiation doses and drug dose to be used as a matrix for immobilization and control drug release of captopril. Immobilization and release of captopril in PVA-PVP hydrogel copolymer have been carried out. A mixture of PVA-PVP $(6: 4 \mathrm{w} / \mathrm{w})$ solution containing captopril (10-20 mg), freeze-thawing, irradiated using gamma rays at various irradiation doses (0-20 kGy). The gel fraction and water absorption were determined gravimetrically. The pores structure of hydrogels were observed using SEM (Scanning Electron Microscope). The captopril released from hydrogel in $\mathrm{NaCl} 0.9 \%$ solution was measured using a UV-Vis spectrophotometer. After evaluated, it was found that with increasing dose up to $20 \mathrm{kGy}$, the gel fraction increases, and water absorption decreases, and the cumulative drug released decreases. SEM measurement showed that hydrogel had heterogeneous pores. PVA-PVP hydrogel prepared using gamma rays can be considered as a matrix for drug release.
\end{abstract}

Keywords: PVA, PVP, Hydrogel, Captopril, Irradiation

\begin{abstract}
ABSTRAK
RADIASI SINTESIS HIDROGEL PVA (POLIVINIL ALKOHOL)-PVP (POLIVINIL PIRRO-LIDON) SEBAGAI MATRIKS IMOBILISASI KAPTOPRIL. Penelitian ini bertujuan membuat hidrogel polvinilalcohol (PVA)-polivinil pirrolidon (PVP) dengan variasi dosis radiasi dan dosis obat untuk digunakan sebagai matriks imobilisasi dan pelepasan terkendali kaptopril. Telah dilakukan imobilisasi dan pelepasan kaptopril dalam matriks hidrogel kopolimer PVA-PVP. Larutan PVA-PVP (6:4\%berat) yang mengandung kaptopril (10 mg - $20 \mathrm{mg})$, dibeku-lelehkan dan diiradiasi sinar gamma pada variasi dosis (0 kGy - 20 kGy). Fraksi gel dan air terserap ditentukan secara gravimetri. Hidrogel dikarakterisasi dengan Scanning Electron Microscope (SEM). Uji pelepasan kaptopril dari hidrogel dilakukan dalam larutan $\mathrm{NaCl}$ $0,9 \%$ dan diukur dengan Spectrofotomer Ultraviolet Visible (Uv-Vis). Hasil evaluasi menunjukkan meningkatnya dosis iradiasi hingga $20 \mathrm{kGy}$, fraksi gel meningkat dan kemampuan menyerap air hidrogel menurun. Pelepasan kumulatif obat dari matrik hidrogel dengan meningkatnya dosis iradiasi hingga $20 \mathrm{kGy}$ relatif menurun. Pengamatan menggunakan SEM menunjukkan hidrogel PVA-PVP berstruktur pori yang tidak teratur. Hidrogel PVA-PVP selayaknya dapat dipertimbangkan sebagai matriks pelepasan obat.
\end{abstract}

Kata kunci: PVA, PVP, Hidrogel, Kaptopril, Iradiasi 


\section{INTRODUCTION}

Captopril is one of the most popular drugs used as antihypertensive inhibitors of active enzyme angiotensin converter (ACE). Nevertheless, the efficacy of captopril as a primary antihypertensive choice after an oral dose is limited in a period of 6 to $8 \mathrm{hr}$. The recent progress and attempts made on the oral sustained or controlled release formulation for captopril. Various methods are available to formulate water soluble drugs into sustained release dosage forms by retarding the dissolution rate such as; matrix tablets, coated tablets, floating tablets, slow release granules,sustai-ned release oily matrix, sustained-release micro-particles, elementary osmotic pump [1-5]. For all these purposes the synthetic or natural polymers are used i.e ethylcellulose, methylcellulose, PVP, gum, agar, microparticle, HPMC, etc. All the controlled release dosage forms available for captopril claims to release the drug up to $8 \mathrm{~h}$. These need the drug administration two to three times a day which is not feasible for once a formulation. In some cases, the optimum release of drug was shown but with in vitro data only. The in vivo release was studied under animals only. Further clinical studies are needed to assess the utility of these systems for patients suffering from hypotension. However extensive studies are required to examine the factors that play role in development of controlled release formulations of captopril. Surprisingly, despite all these research work, there are likely to be no well established captopril controlled release formulations reported to be in the market. In addition, one candidate who has good prospects as a matrix for drug immobilization is a hydrogel. The development of the captopril in the form of the immobilization has advantages, among others: reducing the frequency of drug use and minimizing the fluctuations in blood concentrations of drugs that reduce the side effect [6].

Hydrogels are hydrophilic polymers with threedimensional polymeric network with large molecular weights, and are not soluble in water. They have porous structure, water and small molecules can across the pores easily through diffusion. Their uni-que properties such as biocompatibilty, biodeg-radability, sensitivity to various stimuli and the ability to be conyugated easily with hydrophilic and hydro-phobic theurapatic compounds, has made them impor-tant candidates in drug immobilization [7-10].

The drug immobilization technique on the hydrogel matrix is one of the methods of drug delivery that is developed at this time. Drug immobilization is one technique for entrapping the drug in a matrix whose release in a medium can be controlled. Drug immobilization can generally be done in 2 ways, i.e., postloading and situ loading [11]. On post-loading, the drug is restrained after the matrix is formed; subsequently, the drug is entrapped in a matrix. While in situ loading, the drug is simultaneously restrained in the matrix synthesis. The technique of drug immobilization is entrapping the drug in the physical matrix, the drug does not experience chemical reactions with the matrix, and the drug can be separated from the matrix in controlled intervals in a specific time. In the synthesis of the hydrogel matrix is necessary to use a crosslinker, the hydrogel matrix becomes insoluble with the drug when it is tested. Some types of crosslinkers commonly used for the synthesis of hydrogel include Genipin, Formaldehyde, Glutaraldehyde, diisocyanate, and Tripolifospat [12-14]. The use of crosslinkers generally leaves toxic residue after the hydrogel synthesis process. One of the processes for the good and safe synthesis of hydrogels is through the freeze-thaw process using PVA polymers that do not leave toxic residues [15].

Polyvinyl alcohol (PVA) is one of the raw materials of hydrophilic polymer that is potentially for purposes in the biomedical field, particularly in the release matrix of the drug. PVA is biocompatible, non-toxic, noncarcinogenic [16]. Besides, PVA has the advantage of being able to easily form a crosslinked hydrogel of physics with the technique treatment of freezethaw process [15]. In- freeze state, the water molecule will form the ice crystals trapped in the PVA matrix. When the thawing treatment, the ice crystals stuck in the hydrogel melt out of the PVA hydrogel matrix and leave useful pores for the diffusion of drugs or other molecules. Therefore, PVA has good prospects as a matrix for the release of drugs (drug delivery). The weakness of the PVA hydrogel, among others, its physical surface structure is not elastic. To modify the PVA surface state is generally done copolymerization of PVA with Polyvinyl Pyrrolidone.

Polyvinyl Pyrrolidone (PVP) is a potential hydrophilic polymer for purposes in the field of pharmaceuticals and biomedicine. PVP Polymers are biocompatible, non-toxic, non-carcinogenic, and exhibit elasticity and transparency [17]. The weakness of PVP is difficult to form a hydrogel because its chemical structure is difficult to crosslink and fragile. Therefore, the copolymerization of PVP with PVA through the freeze-thaw technique is the best way to obtain potential new biomedical substances in particular for the immobilization matrix of drugs such as the Captopril. To obtain a sterile product, the freeze-thaw process can be continued with the gamma irradiation process.

The method of immobilization of the drug in a matrix of hydrogels with irradiation techniques has an advantage among other polymers or monomers as the matrix of hydrogels can experience radiation crosslinking reactions, the drug can be trapped in the simultaneous matrix of hydrogels in a cooling state and no degradation occurs, no need for crosslinkers and produced products as well as sterile [18].

Based on the description above, in this study we prepared PVA - PVP hydrogel containing captopril as a 
model of drug-using freezing-thawing and irradiation technique simultaneously. From this work, we expect that the hydrogel PVA-PVP can prolong the release of captopril as well as the effect of irradiation dose or drug compositions.

\section{EXPERIMENTAL METHODS}

\section{Materials}

Captopril was purchased from PT. PERTIWI AGUNG (Landson), Polyvinyl alcohol (PVA) with degree hydrolysis $98 \%$ made in KURARAY, Japan. A Polyvinyl Pyrrolidone (PVP) made by BASF, Germany. $\mathrm{NaCl}$ made in Merck. Distilled water was used for the synthesis of hydrogels.

\section{Gamma Irradiation Sources}

Irradiation samples were carried out in the radiation processing irradiator IRPASENA, BATAN, Pasar jumat with a gamma radiation dose rate of 2.5 $\mathrm{kGy} / \mathrm{h}$. The irradiation processing was carried out at room temperature. The irradiation dose was calibrated using a Fricke dosimeter.

\section{Determination of Water Absorption}

Hydrogel samples of $2 \times 2 \times 0.5 \mathrm{~cm}^{3}$ sizes were dried in an oven at a temperature of $60^{\circ} \mathrm{C}$ until constant weight, then weighed $\left(\mathrm{W}_{0}\right)$. The dried hydrogels were immersed in $25 \mathrm{~mL}$ distilled water. After 1 hour, the hydrogels were removed from the soaking medium. Then, removing the water on the surfaces of hydrogels with filter paper, subsequently, hydrogel weighed (Ws). Afterward, the hydrogels were immersed again in water with the same container for the test of water absorption at the next 1hour duration time interval. The same treatment was done for testing water absorption hydrogel in other hours intervals. Finally, the hydrogels were dried in an oven at $60{ }^{\circ} \mathrm{C}$ until constant weight. Water absorption can be calculated using the following equation,

$$
\text { Water Absorption }=\left(\mathrm{Ws}-\mathrm{W}_{0}\right) / \mathrm{W}_{0} \times 100 \%
$$

$\mathrm{W}_{\mathrm{s}}=$ The weight of swollen hydrogel $(\mathrm{g})$

$\mathrm{W}_{0}^{\mathrm{s}}=$ The weight of dry hydrogel $(\mathrm{g})$

\section{Determination Gel Fraction}

The dried hydrogels were taken into a tea bag and dried in an oven at a temperature of $60{ }^{1 "} \mathrm{C}$ until constant weight, then weighed $\left(\mathrm{W}_{0}\right)$. Besides, the tea bags were immersed in distilled water and shaking in an incubator shaker at $100 \mathrm{rpm}$ for 24 hours at room temperature to extract unreacted compounds due to radiation treatment. Then, the tea bags were removed from the shaker incubator and dried under vacuum at
$60{ }^{\prime \prime} \mathrm{C}$, weighed $\left(\mathrm{W}_{1}\right)$. The gel fraction can be calculated by the following equations (2),

$$
\text { Gel Fraction }=\mathrm{W}_{1} / \mathrm{W}_{0} \times 100 \%
$$

$\mathrm{W}_{0}=$ The initial weight of dry hydrogel $(\mathrm{g})$

$\mathrm{W}_{1}=$ The weight of dry hydrogel after extraction $(\mathrm{g})$ Note : All worl carried out in triplicate

\section{Immobilization of Captopril}

Amixture of PVA $(6 w t \%)$ and PVP $(4 w t \%)$ powder were dissolved in $100 \mathrm{~mL}$ distilled water by autoclaving at a temperature of $121 \mathrm{C}$ for 15 minutes. Furthermore, the samples were taken out and left to cool down to room temperature. Then, the PVA-PVP solution was poured into one series of $3 \mathrm{~mL}$ glass vial, and each vial was added $10 \mathrm{mg}, 20 \mathrm{mg}, 30 \mathrm{mg}$ captopril respectively. Afterward, the solution containing captopril was stirred using a hand shaker until completely homogeneous. then freeze at $-4{ }^{\circ} \mathrm{C}$ for 12 hours and thawing at $25{ }^{\prime \prime} \mathrm{C}$ for 12 hours ( called as 1 cycle process). The process of freezing-thawing was repeated up to three cycles and then irradiated using gamma rays from cobalt- 60 at the doses of $0 \mathrm{kGy}, 10 \mathrm{kGy}, 20 \mathrm{kGy}$ (dose rate $2.5 \mathrm{kGy} / \mathrm{h}$ ). After irradiation, the vials were broken and hydrogels were removed from the vials. Subsequently, each hydrogel was immersed into $100 \mathrm{~mL}$ of $0.9 \% \mathrm{NaCl}$ solutions, shake with a speed of $100 \mathrm{rpm}$ in an shaker incubator at a temperature of $37^{\circ} \mathrm{C}$. Each time interval of 1 hour, $5 \mathrm{~mL}$ of the captopril solution were with drawn for UV-Vis spectrophotometer analysis at maximum wavelength of $\lambda=205 \mathrm{~nm}$ and replaced with $5 \mathrm{ml}$ of the fresh same solvent. The test was carried out on triple. The amount of captopril released from hydrogels was calculated as percent cumulative.

\section{Scanning Electron Microscopy (SEM)}

The surface characteristics of the PVA-PVP hydrogel were investigated using the Scanning Electron Microscope (SEM), Zeiss, made in Germany. The dried samples were soaked in distilled water to maximum swelling. Then, the hydrogels were frozen in the freezer at $-25{ }^{\circ} \mathrm{C}$ for 48 hours. Then, the hydro-gels were lyophilized using freeze-drying at $-40{ }^{\circ} \mathrm{C}(24 \mathrm{~h})$. Dried hydrogels were then observed for surface properties using SEM and recorded.

\section{RESULTS AND DISCUSSION}

\section{Gel Fraction}

The gel fraction as one of the main parameters can be used to study the physical properties of hydrogels. This parameter is used to know the efficient technique for the conversion of the materials based on hydrogels, or it can also be used to determine the 


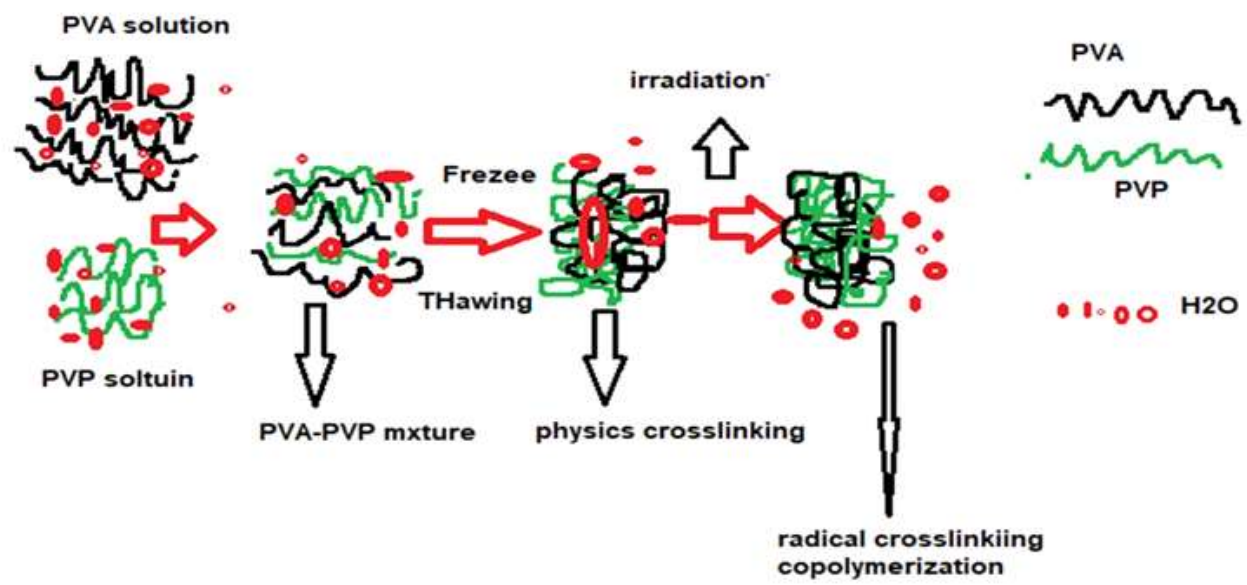

Figure 1. Freeze-thawing and irradiation mechanism of PV-PVP blended hydrogel preparation.

crosslink density formed in the hydrogels [19]. PVA-PVP hydrogel crosslinked was conducted by a two steps process: 1) freeze-thawing and 2) radiation, and their mechanism scheme is presented in Figure 1. In the first step, a mixture of PVA-PVP solution in the freeze-thaw in 1 cycle produces PVA-PVP hydrogels formed based on a physics crosslink. Thus the degree of the gel fraction can be determined. The hydrogels were produced from freeze-thawing steps also widely used for potential biomedical applications [15]. If in the PVA-PVP mixture contained captopril. The captopril will be frozen at the surfaces and entrapped inside the hydrogels randomly. The gel fraction obtained by the freeze-thawing process usually not optimal and the hydrogel not sterile. For efficiency of process conversion, raw materials to products can be continued by sterilization radiation simultaneously.

The gel fraction of PVA-PVP hydrogel produced by gamma radiation radical copolymerization from $0 \mathrm{kGy}$ to $20 \mathrm{kGy}$ is presented in Figure 2. It can be seen that with increasing irradiation dose of up to $20 \mathrm{kGy}$, the gel fraction is increased from $60 \%$ to $89.5 \%$. The gel fraction of hydrogels without radiation treatment $(0 \mathrm{kGy})$ or the hydrogels produced by the freeze-thawing process only is about $60 \%$, indicating that the freeze-thawing process is unable to convert the PVA-PVP mixture into $100 \%$

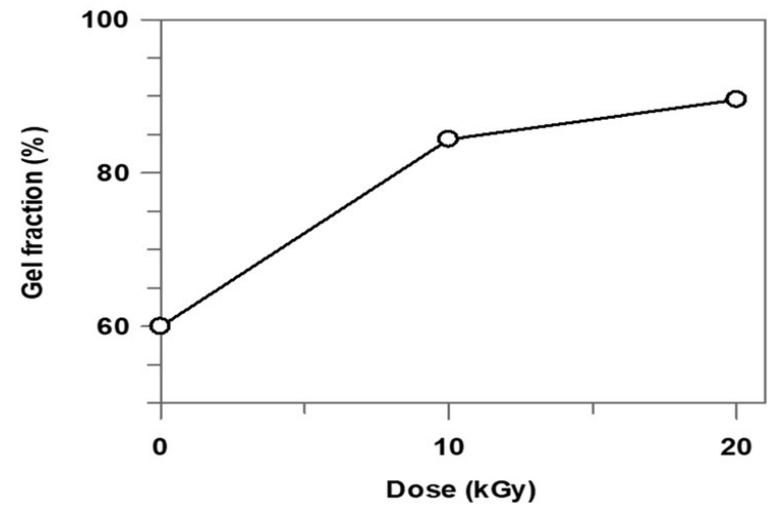

Figure 2. Effect of irradiation dose vs. hydrogel fraction gel PVA-PVP at dose $0 \mathrm{kGy}$ to $20 \mathrm{kGy}$. hydrogel completely. Moreover, irradiation treatment up to $20 \mathrm{kGy}$ increased PVA-PVP gel fraction to $89.5 \%$, gel fraction is increased about to $28.5 \%$. The occurrence of gel fraction increases due to the formation of chemical crosslinking between PVA-PVP as well as the radical reaction of radiation copolymerization. Gamma radiation influences the synthesis of PVA-PVP hydrogels is quite efficient, because only $11.5 \%$ of raw materials are wasted, and perhaps with increased doses irradiated $>20 \mathrm{kGy}$ can increase the gel fraction. Radiation treatment is not only for a radical crosslinking hydrogel formed. But, there is also a probable degradation reaction of PVA, PVP, and captopril during the irradiation process that results in water-soluble degradation products or unreacted PVA and PVP polymers.

The mechanism of immobilization of captopril in the PVA-PVP hydrogel through a combination freezethawing and irradiation process is essentially the same as the process presented in Figure 1, only in the mixture containing captopril. In the freezing-thawing process, the captopril is randomly dispersed in the PVA-PVP mixture and freezes on the surface and entrapped inside hydrogel, and reacts physically. If the captopril in the frozen is irradiated, then the relatively small frozen captopril experienced a degradation reaction. This is one of the methods of choice for drug immobilization using irradiation techniques that can simultaneously strengthen the hydrogel matrix from being soluble in water through a crosslinking polymerization radical reactions.

\section{Water Absorption}

The ability of hydrogels to absorb water is one of the critical parameters to predict its capacity for drug release. The effect of radiation dose up to $20 \mathrm{kGy}$ on water absorption of PVA-PVP hydrogels is presented in Figure 3. It can be seen that at the initial first-hour determination, the PVA-PVP hydrogel prepared by irradiation at the dose ranged of $0-20 \mathrm{kGy}$, its capacity to absorb water is from $310 \%$ to $450 \%$. With increasing 
immersion time of up to 6 hours, hydrogel's ability to absorb water gradually increased from $640 \%$ up to $820 \%$. It contrasts to the effect of the radiation dose that with an increasing dose of radiation up to $20 \mathrm{kGy}$, the hydrogel ability to absorb water decreased from $820 \%$ to $640 \%$ at the end of the determination ( $6^{\text {th }}$ hour). The water absorption mechanism in hydrogels is initially beginning by wetting of its surface through hydrogen bonding, ionic interaction, and hydrophobic interactions. After a saturated condition on the hydrogel's surface, there is a coil opening in the hydrogel, and the hydrogel begins to swelling, the pore pores start to open and the water enters the pores. Water movement in the pore runs continuously to the equilibrium condition that is no longer occurs swell, and the hydrogel indicated a constant sloping curve shape.

In Figure 3, it is seen that the water absorption of prepared hydrogels without irradiation treatment of 0 kGy (control), are higher than the water absorption of the irradiated hydrogels of $10 \mathrm{kGy}$ and $20 \mathrm{kGy}$. Hydrogels from $0 \mathrm{kGy}$ is a hydrogel produced from the freeze-thawing process in which the ice is still trapped in a matrix of hydrogels. When the ice melts and then makes the pores that easier for the water molecules to come out and in the pores. So that the ability of hydrogels to absorb water increases. While the hydrogel produced with an increase in irradiation dose up to $20 \mathrm{kGy}$ causes the water absorption ability to decrease. This is due to increasing the dose of irradiation, the crosslinking density in the hydrogel increases and the ability of the hydrogel to absorb water becomes decreases.

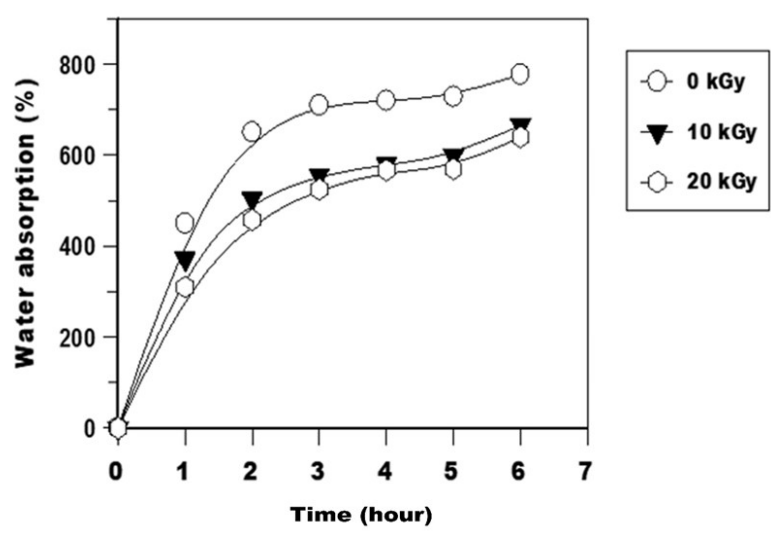

Figure 3. Effect of immersion time vs. water absorption of hydrogel PVA-PVP irradiated $0 \mathrm{kGy}, 10 \mathrm{kGy}$, and 20 kGy..

\section{In Vitro Release of Captopril from Freeze- Thawing (0 kGy) Hydrogel}

The results of immersion time in $0,9 \mathrm{NaCl}$ solution on the cumulative in vitro release of the Captopril from PVA - PVP hydrogels of freeze -thawing process or without irradiation treatment $(0 \mathrm{kGy})$, each hydrogel containing 10.20 and $30 \mathrm{mg}$ of Captopril are presented in
Figure 4. It is seen that with increasing the immersion time from the 1 st hour to the $7^{\text {th }}$ hour, the cumulative amount of the captopril release from the hydrogel is increased gradually. At initial testing ( $1^{\text {st }}$ hour), it can be seen that the cumulative drug released from hydrogel is higher from 3 up $6 \%$ relatively. These phenomena are known as burst release effect and occurs due to through diffusions and swelling process of the hydrogel. The typical curve-release profile of the burst release of captopril that appeared is a kinetics order 1 of drug release [19].

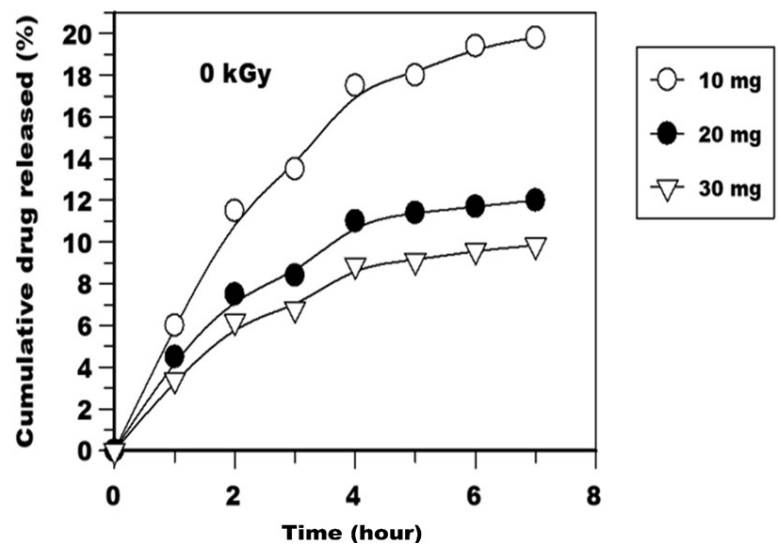

Figure 4. Immersion-time vs. cumulative captopril released from the PVA-PVP hydrogel as function of a drug dose .

The release of the captopril of the hydrogel (drug dose $10 \mathrm{mg}$ ) in testing media of $0.9 \% \mathrm{NaCl}$ up to the 7 th hour measurement is reached a \% cumulative release to appproximately $20 \%$. While the hydrogels containing 20 $\mathrm{mg}$ and $30 \mathrm{mg}$ Captopril, their cumulative drug release reaches $12 \%$ and $10 \%$. Be clear that with increasing of the Captopril loaded into hydrogels, the amount of drug release decreases. This is due to the increasing amount of the Captopril loaded in the hydrogel, the hydrogels are to be dense. The ability of water diffusion in the pores of hydrogel becomes difficult and the drug release from the hydrogel becomes low.

\section{Effect of Radiation Doses Against in Vitro Release of Captopril}

The relationship between immersion time and in vitro release of the captopril from the PVA- PVP hydrogel as a function radiation doses from $0 \mathrm{kGy}$ up to $20 \mathrm{kGy}$, each hydrogel containing different doses of captopril (10-30 mg) is presented in Figure $5 \mathrm{~A}, \mathrm{~B}$, and $\mathrm{C}$.

Figure 5. In general, it can be seen that with increasing immersion time, the capability of hydrogel resulting from the freeze-thawing process $(0 \mathrm{kGy})$ in which containing different amounts of captopril (10 to $30 \mathrm{mg}$ ) only can tested up to 7 hours of testing. Additionally, the cumulative percentage of the captopril released up to 7 hours testing ranging from 10 to $20 \%$. In the next hours, the percent cumulative of the 

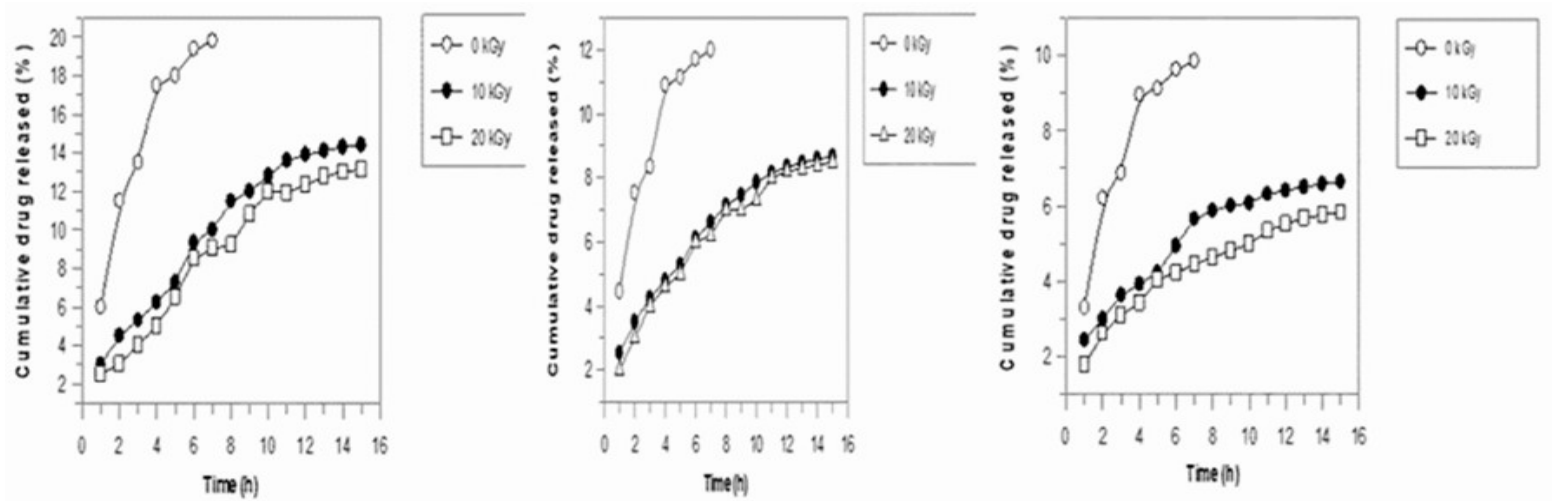

Figure 5. The immersion time vs. the cumulative of captopril in vitro release from PVA-PVP hydrogel as a function of radiation doses with different amounts of drug A) $10 \mathrm{mg}$, B) $20 \mathrm{mg}$, C) $30 \mathrm{mg}$.

drug released from the hydrogel can not be tested again, because the hydrogel is already degraded. It is indicated that the PVA-PVP hydrogel of freeze results without experiencing the irradiation process will be easily degraded. Whereas hydrogel results in irradiation treatment of $10 \mathrm{kGy}$ and $20 \mathrm{kGy}$, the ability of the hydrogel to release the drug can be tested until it reaches 15 hours of testing with percentage cumulative drug released in the range of 6 to $14 \%$. Besides, the remaining the drug in each matrix of hydrogel approximately 86 to $94 \%$. This indicates that the PVA-PVP hydrogel produced from radiation treatment is better and stronger as the matrix of drugs compared to PVA-PVP hydrogels that are only treated by the freeze-thawing process $(0 \mathrm{kGy})$. The ability to release the captopril within a measurement period of 15 hours and a relatively large remaining drug (86-94\%), PVA-PVP hydrogels can be a candidate for the controlled release of drugs. The release of the drug from the matrix is due to the combination diffusion and swelling of the hydrogel [20]. Besides, each hydrogel at the beginning of the test ( 1 st hour \} indicates a profile burst release in the range of $2-6 \%$. The release profile is shown in Figure $5 \mathrm{~A}, \mathrm{~B}$, and $\mathrm{C}$ is as a drug release profile burst release with the kinetics order 1 of the hydrogel degraded such as the irradiated PVA-PVP hydrogel.

\section{SEM Hydrogel}

Photomicrograph Scanning Electron micrograph (SEM) provides information on the geometry morphology of pores and hydrogel size in specific locations. The morphology of the PVA-PVP hydro-gel surface that contains the captopril is presented in Figures 6(a) and 6(b). The SEM photos in Fig. $6 \mathrm{~A}$ and $6 \mathrm{~B}$ provide relevant information about the homogeneity and heterogeneity of the hydrogels. The morphology of the surface and inner (interior) hydrogel PVA-PVP hydrogel with a magnification of 500x. It is apparent that the fiber hydrogel surfaces consist of irregular pores with a pore size range of $7.5-15 \mu \mathrm{m}$ in figure $6 \mathrm{~A}$, and a thick polymer skin covers a pore size range of $6.25-18,75$ $\mu \mathrm{m}$ and some locations. There is also the remain of the captopril drug on the hydrogel surface. The thick skin of the polymer is caused by the collapse of pore surfaces in the freeze-drying process, especially by large pores and hydrogel wall skin. The presence of pores of this hydrogel is one of the factors that cause the release of the drug from the hydrogel through the diffusion process of water in the pores.

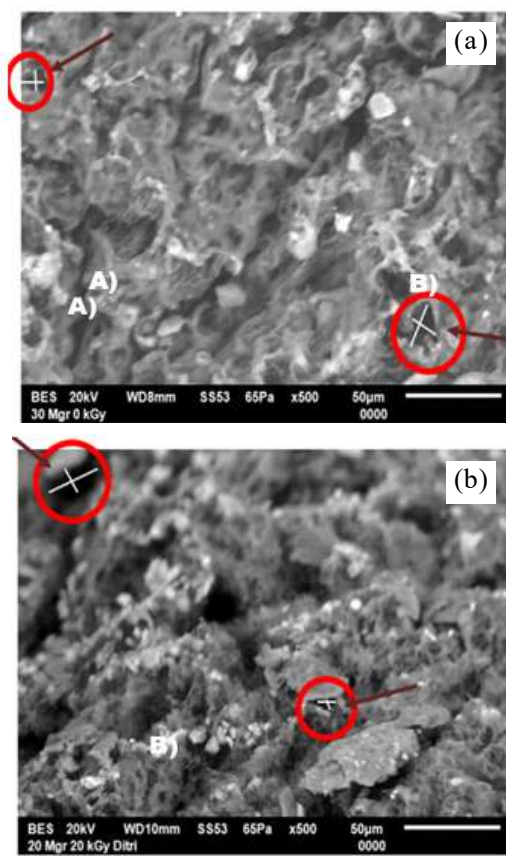

Figure 6. Photomicrograph SEM hydrogel PVA-PVP irradiation result, (a) $0 \mathrm{kGy}$ and (b) $20 \mathrm{kGy}$ containing captopril with magnification $500 \mathrm{X}$.

\section{CONCLUSION}

PVA- PVP radiation crosslinking hydrogel has been successfully synthesized via a combination of freezing-thawing and gamma irradiation for the immobilization of captopril. Captopril is suitable as a model for immobilization in the PVA-PVP hydrogel The increase in irradiation doses of up to $20 \mathrm{kGy}$ caused the hydrogel gel fraction to increase, but the water absorption decreases. The release of the captopril of 
the PVA-PVP hydrogel depends on the dose of irradiation and the drug. The release of the drug on the hydrogel without irradiation treatment $(0 \mathrm{kGy})$ can only be tested for up to 7 hours, testing over 7 hours of the hydrogels will degradation. Increasing the irradiation dose to $20 \mathrm{kGy}$ and the drug dose up to $30 \mathrm{mg}$, causing the rate of release of the captopril decreases. Increasing the immersion time, the release of the captopril slowly increases in test media. The release of the PVA-PVP hydrogel is a characteristic burst release profile with order kinetics of 1 . Due to the percentage of the captopril cumulative amount released about $20 \%$ relatively small up to 15 hours, and with a percentage of the remaining captopril about $80 \%$ in the hydrogel; the PVA-PVP hydrogel should be considered as a slow-release of the drug.

\section{ACKNOWLEDGEMENT}

I would like to express my very great appreciation to Mr. Bonang from IRPASENA BATAN who helped irradiation the samples until this research was completed.

\section{REFERENCES}

[1] J. Sauri, M Zachariah, R. Macovez, M Sure pou, M. Minarro, JR Tico, JM Sune Negre, "Formulation and characterization of mucoadhesive controlled release matrix tablets of captopril." Journal Delivery Science and Technology, vol. 42, pp. 215-226, Dec. 2017.

[2] J. L. J. Blanco, J. M. Benito, C. O. Melleta, J. M. G. Fernández, "Molecular nanoparticle-based gene delivery systems." Journal of Drug Delivery Science and Technology, vol 42, pp. 18-37, Dec. 2017.

[3] D. K. Kurniawan, D. A. Triyanto, V. V. Fera, R. Utami, "Sustained Release of Captopril Tablet with Floating System Using a Cross-Linked Matrix of Alginate." Kartika : Jurnal Ilmiah Farmasi, vol. 6, 1, Jun. 2018.

[4] K. V. R. N. S. Ramesh, S. M. Layam, O. Sarheed, Q. Islam, G. G. Krishna, "Design and evaluation of single and multi-unit sustained release dosage forms of captopril." Asian Journal of Pharmaceutics, vol. 11, pp.118-128, Apr. 2017.

[5] M. T. R. Chikukwa, R. B. Walker , S. M. M. Khamanga, "Formulation and Characterisation of a Combination Captopril and Hydrochlorothiazide Microparticulate Dosage Form." Pharmaceutics, vol. 12, 712, Jul. 2020.

[6] X. Bai, X. Q. Zhang, “ Bioactive hydrogels for bone regeneration." Bioactive Materials. Vol. 3, pp. 401-417, 2018

[7] Y. C. Qian, P. C. Chen, G. J. He, X. J. Huang, Z. K. $\mathrm{Xu}$ " Preparation of Polyphosphazene Hydrogels for Enzyme Immobilization," Molecules, vol. 19, 9850-9863, Jul. 2014

[8] E. Erizal, E. W. Pratiwi, D. P. Perkasa, N. Noviyantih, B. Abbas, S. Sudirman," Immobilization of propanolol hcl in poly(vinyl alcohol) - sodium alginate hydrogel using irradiation technique." Jurnal Kimia Kemasan, vol. 40, pp. 47-56, Apr. 2018

[9] Z. Velkova, G. Kirova, M. Stoytcheva, S. Kostadinova, K. Todorova, V. Gochev, "Immobilization of Bacterial Cells in Hydrogels Prepared by Gamma Irradiation for Bioremoval of Strontium Ions.” Engineering in Life Sciences, vol. 18, pp. 871-881, Jul. 2018

[10] D. Singh, A. Singh, R. Singh, "Polyvinyl pyrrolidone/carrageenan blend hydrogels with nanosilver prepared by gamma radiation for use as an antimicrobial wound dressing." Journal of Biomaterials Science, Polymer Edition, vol. 26. pp. 1269-1285, Sept. 2015.

[11] R. Shet, H. Won , K. Dodou, "Effect of Drug Loading Method and Drug Physicochemical Properties on the Material and Drug Release Properties of Poly (Ethylene Oxide) Hydrogels for Transdermal Delivery.” Polymers, vol. 9, 286, Jul. 2017.

[12] I. Dmitriev, I. Kuryndin, N. Bobrova, M. Smirnov, "Swelling behavior and network characterization of hydrogels from linear polyacrylamide crosslinked with glutaraldehyde." Materials Today Communications, vol. 4, pp.93-100, Sept. 2015.

[13] S. Dimida, C. Dimitri, V. D. Benedictus, F. Scalera, "Genipin crosslinked chitosan based hydrogels: Reaction kinetics and structure related characteristics,"Jounal of Applied Polymer Science, vol.132, pp. 42256, Apr. 2015.

[14] M. Ubaid, S. N. H. Shah, S .A. Khan, G. Murtaza, "Synthesis and Characterization of $\mathrm{pH}-$ Sensitive Genipin Cross-Linked Chitosan-/Eudragit ${ }^{\circledR}$ L100 Hydrogel for Metformin Release Study Using Response Surface Methodology." Current Drug Delivery, vol. 15, pp. 1343-1358, Apr. 2018.

[15] M. D. Figueroa-Pizano, I. Velaz, F. J. Penas, P. Zavala-Rivera, A. J. Rosas-Durazo, A. D. Maldonado-Arce, M. E. Martinez-Barboza, "Effect of freeze-thawing conditions for preparation of chitosan-poly (vinyl alcohol) hydrogels and drug release studies." Carbohydrate Polymers, vol. 195. pp. 476-485. Sept. 2018.

[16] T. S. Gaaz, A. B. Sulong, M. N. Akhtar, A. A. H. Kadhum, A. B. Mohamad, A. A. Al-Amiery, "Properties and Applications of Polyvinyl Alcohol, Halloysite Nanotubes and Their Nanocomposites." Molecules, vol. 20, pp. 22833-22847, Dec. 2015

[17] P. Franco, I. De Marco, "The Use of Poly(N-vinyl pyrrolidone) in the Delivery of Drugs: A Review." Polymers, vol. 12, 1114, Jun. 2020. 
[18] W. Radoslaw, A. W. Agnieszka, O. Alicja, M. Malgorzata, A. Charito, U. Piotr. (2020). "Carboxymethylchitosan hydrogel manufactured by radiation-induced crosslinking as potential nerve regeneration guide scaffold. Reactive and Functional Polymers. Vol. 152. 104588, Jul. 2020

[19] R. Dwivedia, A. K. Singh, A. Dhillona, "pHresponsive drug release from dependal-M loaded polyacrylamide hydrogels.", Journal of Science: Advanced Materials and Devices, vol. 2, pp. 4550, Mar. 2017,

[20] M. Miotke, J. Strankowska, J. Kwela, M. Strankowski, M. Józefowicz, "Transport of paracetamol in swellable and relaxing polyurethane nanocomposite hydrogels," Polymer Bulletin, vol. 77, pp. 483-499, Apr. 2019. 